\title{
EFFECT OF PROCESS PARAMETERS ON THE MICROSTRUCTURE AND MECHANICAL PROPERTIES OF FRICTION-WELDED JOINTS OF AISI 1040/AISI 304L STEELS
}

\author{
VPLIV PROCESNIH PARAMETROV NA MIKROSTRUKTURO IN \\ MEHANSKE LASTNOSTI TORNO VARJENIH SPOJEV JEKEL \\ AISI 1040/AISI 304L
}

\author{
İhsan Kirik ${ }^{1}$, Niyazi Özdemır ${ }^{2}$ \\ ${ }^{1}$ Batman University, Department of Metallurgy and Material Engineering, 72060 Batman, Turkey \\ ${ }^{2}$ Firat University, Department of Metallurgy and Materials Engineering, 23119 Elazığg, Turkey \\ alihsankirik@gmail.com \\ Prejem rokopisa - received: 2014-09-17; sprejem za objavo - accepted for publication: 2014-10-17
}

doi: $10.17222 /$ mit.2014.235

\begin{abstract}
Couples of AISI 304L and AISI 1040 steels were welded using the continuous-drive friction-welding process. The welded joint were manufactured using three different rotational speeds $((1300,1500$ and 1700$) \mathrm{r} / \mathrm{min})$, three different frictional pressures and three different frictional times. To determine microstructural changes, the interface regions of the welded samples were examined by scanning electron microscopy (SEM), X-ray diffraction (XRD) and energy dispersive spectrometry (EDS). Microhardness and tensile tests of the welded samples were conducted. The results show that the properties of the microstructures are significantly changed and the interface temperature increased with the frictional time. An excellent tensile strength was observed for the joint made at a rotational speed of $1700 \mathrm{r} / \mathrm{min}$ and a frictional time of $4 \mathrm{~s}$.

Keywords: friction welding, AISI 1040 steel, AISI 304L steel
\end{abstract}

Jekli AISI 304L in AISI 1040 sta bili zvarjeni z uporabo kontinuirnega tornega procesa varjenja. Zvarjeni spoji so bili izdelani pri treh različnih hitrostih vrtenja $((1300,1500$ in 1700$) \mathrm{r} / \mathrm{min})$, treh različnih tornih tlakih in treh različnih tornih časih. Za določitev mikrostrukturnih sprememb je bilo stično področje zvarjenega vzorca preiskano z vrstičnim elektronskim mikroskopom (SEM), z rentgensko difrakcijo (XRD) in z energijsko disperzijsko rentgensko spektrometrijo (EDS). Izvršeni so bili preizkusi mikrotrdote in natezni preizkusi varjenih vzorcev. Rezultati kažejo, da se mikrostruktura omembe vredno spremeni in da se temperatura stika povišuje s časom trenja. Odlična natezna trdnost stika je bila ugotovljena pri spoju s hitrostjo vrtenja $1700 \mathrm{r} / \mathrm{min}$ in pri tornem času $4 \mathrm{~s}$.

Ključne besede: torno varjenje, jeklo AISI 1040, jeklo AISI 304L

\section{INTRODUCTION}

Stainless steels are iron-based alloys containing 8-25\% nickel and 12-30\% chromium, resisting both corrosion and high temperature. Generally, stainless steels can be classified as martensitic, ferritic and austenitic. Austenitic stainless steels represent the largest group of stainless steels and are produced in higher tonnages than any other group. They have a good corrosion resistance in most environments. Austenitic stainless steel can be strengthened significantly by cold working and are often used in the applications requiring a good atmospheric or elevated-temperature corrosion resistance.

In spite of a wide variety of austenitic stainless steel, the 300 -series alloys, based on the $18 \mathrm{Cr}-8 \mathrm{Ni}$ system, are the oldest and most commonly used. ${ }^{1-5}$ Type 304 is the foundation of this alloy series and, along with $304 \mathrm{~L}$, it represents the most commonly selected austenitic grade. Although austenitic alloys are generally considered to be very weldable, they are subjected to a number of weldability problems if proper precautions are not taken. Liquation cracking and weld solidification may occur depending on the composition of the base, the filler metal and the level of impurities, particularly S and P. In spite of the good general corrosion resistance of austenitic stainless steels, they may be subject to localized forms of corrosion at grain boundaries and in the heataffected zone. For joining dissimilar materials, conventional fusion welding is used. However, this method has a lower efficiency when compared to the friction-welding method..$^{5-7}$

The friction-welding process is a solid-state welding process producing welds due to a compressive-force contact of two workpieces: one is rotating and the other is stationary. ${ }^{8,9}$ The heat is generated at the weld interface due to a continuous rubbing of the contact surfaces, while the temperature rises and softens the material. Eventually, the material at the interface starts to flow plastically and forms an upsetting. When a certain amount of upsetting occurs, the rotation is stopped and the compressive force is maintained or slightly increased to consolidate the joint. The fundamental parameters of the friction-welding $(\mathrm{FW})$ process are the rotational speed, the frictional pressure and time, and the forging pressure and time. The advantages of friction welding are a high material saving, a short production time and the possi- 
bility of joining different metals or alloys. This method can also be used to join the components that have circular or non-circular cross-sections. ${ }^{10-17}$

In this study, parts of the AISI 304L austenitic stainless steel and AISI 1040 carbon steel with equal diameters were welded using the friction-welding method. The strengths of the joints were determined with tensile tests and compared with those of the base materials. Then, the hardness variations and microstructures of the welding zones were obtained and investigated using macro- and microphotographs.

Table 1: Chemical compositions of test materials in mass fractions Tabela 1: Kemijska sestava materialov za preizkuse v masnih deležih

\section{EXPERIMENTAL PROCEDURES}

The workpieces used in this work were $\varnothing 12 \mathrm{~mm}$ rods of AISI 1040 and AISI 304L austenitic stainless steels. The nominal chemical compositions and mechanical properties of the materials used are shown in Tables 1 and 2, respectively. The AISI 1040 medium-carbon steel and the AISI 304L austenitic stainless steel were joined with a PLC-controlled continuous-drive frictionwelding machine using different rotational speeds, frictional times and frictional pressures, as indicated in Table 3. The temperature of the welded zone during the

\begin{tabular}{|c|c|c|c|c|c|c|c|c|}
\hline \multirow{2}{*}{ Materials } & \multicolumn{8}{|c|}{ Alloying elements $(w / \%)$} \\
\hline & $\mathrm{C}$ & $\mathrm{Mn}$ & $\mathrm{P}$ & $S$ & $\mathrm{Cr}$ & Mo & $\mathrm{Ni}$ & $\mathrm{Fe}$ \\
\hline AISI 1040 & $0.37-0.44$ & $0.60-0.90$ & 0.040 & 0.050 & - & - & - & Balance \\
\hline AISI 304L & 0.042 & 1.47 & 0.032 & 0.032 & 18.25 & 0.30 & 8.09 & Balance \\
\hline
\end{tabular}

Table 2: Mechanical properties of parent materials

Tabela 2: Mehanske lastnosti izhodnih materialov

\begin{tabular}{|c|c|c|c|}
\hline Material & Hardness (HV) & Yield strength (MPa) & Tensile strength (MPa) \\
\hline AISI 1040 & 165 & 215 & 630 \\
\hline AISI 304L & 210 & 380 & 700 \\
\hline
\end{tabular}

Table 3: Process parameters used in friction welding

Tabela 3: Procesni parametri, uporabljeni pri tornem varjenju

\begin{tabular}{|c|c|c|c|c|c|c|c|c|c|}
\hline \multirow[b]{2}{*}{ Samp. No } & \multicolumn{9}{|c|}{ Welding parameters } \\
\hline & $\begin{array}{c}\text { Rotational } \\
\text { speed } \\
(\mathrm{r} / \mathrm{min})\end{array}$ & $\begin{array}{l}\text { Frictional } \\
\text { time } \\
\text { (s) }\end{array}$ & $\begin{array}{c}\text { Frictional } \\
\text { pressure } \\
(\mathrm{MPa})\end{array}$ & $\begin{array}{c}\text { Forging } \\
\text { pressure } \\
(\mathrm{MPa})\end{array}$ & $\begin{array}{l}\text { Forging } \\
\text { time } \\
\text { (s) }\end{array}$ & $\begin{array}{c}\text { Axial short. } \\
(\mathrm{mm})\end{array}$ & $\begin{array}{l}\text { Max. temp. } \\
\quad\left({ }^{\circ} \mathrm{C}\right)\end{array}$ & $\begin{array}{c}\text { Max. } \\
\text { hardness } \\
(\mathrm{HV})\end{array}$ & $\begin{array}{c}\text { Max. tensile } \\
\text { stren. } \\
(\mathrm{MPa})\end{array}$ \\
\hline $\mathrm{S} 1$ & 1300 & 8 & 30 & 60 & 4 & 6 & 1204 & 362 & 371.414 \\
\hline $\mathrm{S} 2$ & 1300 & 8 & 40 & 80 & 4 & 7 & 1189 & 311 & 412.431 \\
\hline S3 & 1300 & 8 & 50 & 100 & 4 & 8 & 1105 & 400 & 483.223 \\
\hline S4 & 1300 & 6 & 30 & 60 & 3 & 5 & 1176 & 348 & 387.026 \\
\hline S5 & 1300 & 6 & 40 & 80 & 3 & 6 & 1102 & 317 & 559.276 \\
\hline S6 & 1300 & 6 & 50 & 100 & 3 & 7 & 1152 & 312 & 600.061 \\
\hline S7 & 1300 & 4 & 30 & 60 & 2 & 4 & 1214 & 330 & 580.338 \\
\hline S8 & 1300 & 4 & 40 & 80 & 2 & 5 & 1124 & 277 & 599.821 \\
\hline S9 & 1300 & 4 & 50 & 100 & 2 & 6 & 1182 & 254 & 617.106 \\
\hline S10 & 1500 & 8 & 30 & 60 & 4 & 7 & 1175 & 320 & 473.096 \\
\hline S11 & 1500 & 8 & 40 & 80 & 4 & 8 & 1104 & 376 & 575.716 \\
\hline S12 & 1500 & 8 & 50 & 100 & 4 & 9 & 1123 & 329 & 596.613 \\
\hline S13 & 1500 & 6 & 40 & 60 & 3 & 6 & 1140 & 319 & 588.216 \\
\hline S14 & 1500 & 6 & 40 & 80 & 3 & 7 & 1164 & 337 & 599.296 \\
\hline S15 & 1500 & 6 & 50 & 100 & 3 & 8 & 1129 & 278 & 611.714 \\
\hline S16 & 1500 & 4 & 30 & 60 & 2 & 4.5 & 1104 & 356 & 586.311 \\
\hline S17 & 1500 & 4 & 40 & 80 & 2 & 5.5 & 1185 & 361 & 603.196 \\
\hline S18 & 1500 & 4 & 50 & 100 & 2 & 6 & 1075 & 256 & 588.807 \\
\hline S19 & 1700 & 8 & 30 & 60 & 4 & 8 & 1089 & 321 & 531.222 \\
\hline $\mathrm{S} 20$ & 1700 & 8 & 40 & 80 & 4 & 9 & 1067 & 342 & 563.691 \\
\hline S21 & 1700 & 8 & 50 & 100 & 4 & 10 & 1075 & 263 & 568.780 \\
\hline S22 & 1700 & 6 & 30 & 60 & 3 & 7 & 1125 & 349 & 573.808 \\
\hline $\mathrm{S} 23$ & 1700 & 6 & 40 & 80 & 3 & 7.5 & 1093 & 322 & 589.467 \\
\hline S24 & 1700 & 6 & 50 & 100 & 3 & 8.5 & 1143 & 245 & 571.993 \\
\hline S25 & 1700 & 4 & 30 & 60 & 2 & 4.5 & 1089 & 364 & 592.684 \\
\hline S26 & 1700 & 4 & 40 & 80 & 2 & 5.5 & 1092 & 300 & 612.923 \\
\hline S27 & 1700 & 4 & 50 & 100 & 2 & 6.5 & 1047 & 210 & 637.500 \\
\hline
\end{tabular}


İ. KIRIK, N. ÖZDEMIR: EFFECT OF PROCESS PARAMETERS ON THE MICROSTRUCTURE ...
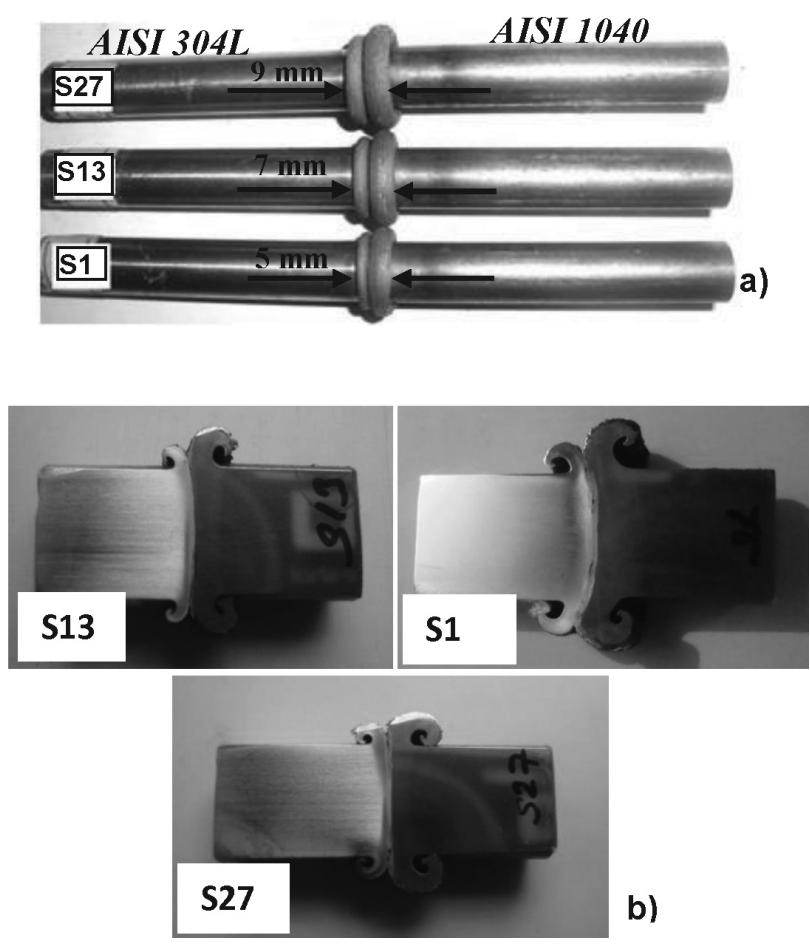

Figure 1: a) Surface and b) cross-sectional macro-images of FW joints of samples S1, S13 and S27

Slika 1: a) Površina in b) makrovidez prečnega prereza FW-spoja pri vzorcih S1, S13 in S27

welding process was measured with an IGA 15 PLUS device. After the friction welding, the microstructural changes in the interface regions of the joints were examined with scanning electron microscopy (SEM), $\mathrm{X}$-ray diffraction (XRD) and energy dispersive spectrometry (EDS). Microhardness and tensile tests were con- ducted and the fracture surfaces of the tensile-test samples were investigated.

\section{RESULTS AND DISCUSSIONS}

\subsection{Evaluation of macro- and microstructural proper- ties}

Figures 1a and 1b show macro-images of the surfaces and interfaces of the friction-welded joints with three different frictional times, respectively. From the figures, the materials of the overflow out of the interfaces are seen to be clean-cut, and the widths of the flashes are measured to be $(5,7$ and 9) $\mathrm{mm}$ for the frictional times of (4, 6 and 8) s, respectively. When joining dissimilar materials by friction welding flash is formed, depending on the mechanical properties of the materials. The extent of the flash increased with the increasing rotational speed, frictional time and frictional pressure. The flash diameter of the joints was larger for the AISI 1040 steel than for the AISI 304L steel. There are no cracks, cavities or disconnected regions seen on the samples joined at a rotational speed of $1700 \mathrm{r} / \mathrm{min}$.

Table 3 shows the axial shortening of the frictionwelded joints. As it can be seen from these results, the axial-shortening values for the materials are different owing to the plastic deformation of the materials. The axial shortening increases with the increasing rotational speed, frictional time and frictional pressure due to the increasing heat input and plastic deformation in the interface of the friction-welded joints. The maximum axial shortening is seen on S21 (10 mm) welded at the following process parameters: rotational speed is 1700
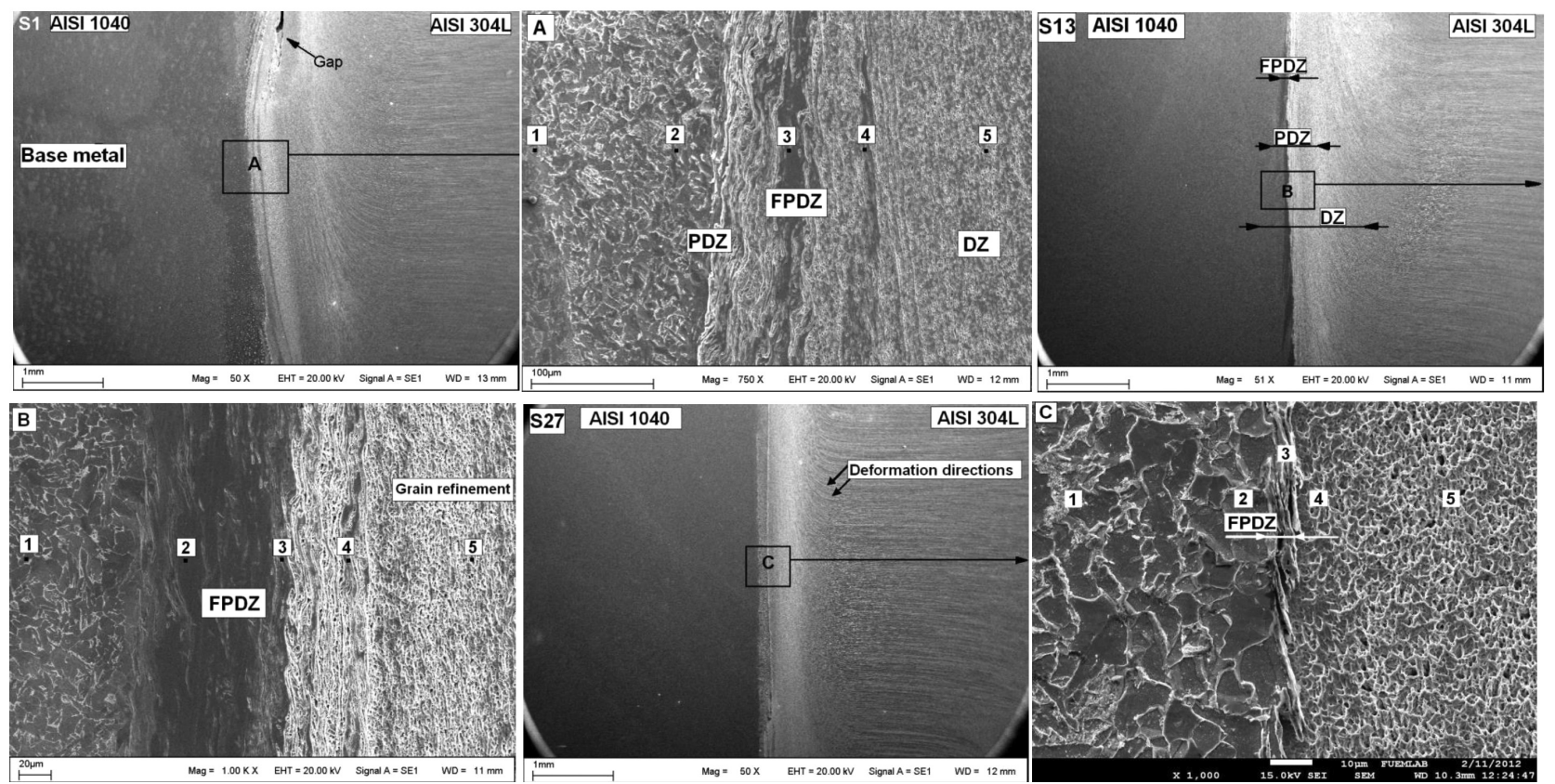

Figure 2: SEM micrographs of the weld zones of the S1, S13 and S27 samples

Slika 2: SEM-posnetki področja zvara pri vzorcih S1, S13 in S27 
$\mathrm{r} / \mathrm{min}$, frictional pressure $50 \mathrm{MPa}$, forging pressure 100 $\mathrm{MPa}$, frictional time $8 \mathrm{~s}$, forging time $4 \mathrm{~s}$.

Figure 2 shows the joint microstructures for samples $\mathrm{S} 1, \mathrm{~S} 13$ and S27 obtained at three different rotational speeds. On Figure 2 distinct regions are seen in the heat-affected zone and the interface of the S1 joint. As reported in the references, the evaluation of the microstructures of the joints revealed different zones in all the samples that were identified as the base metal (BM), the partially deformed zone (PDZ), the deformed zone (DZ) and the fully plasticized deformed zone (FPDZ) $)^{13,15,17}$. In $\mathrm{S} 1$, some disconnected regions and gaps were observed with SEM. In addition, the widths of the FPDZ and DZ expand, and the irregularities observed on all the samples were due to the decreasing frictional and forging pressure, and increasing frictional time. In the SEM micrographs of sample S1, the width of the deformed zone and the irregularity are increased due to a low frictional pressure and a high frictional time. The pressure
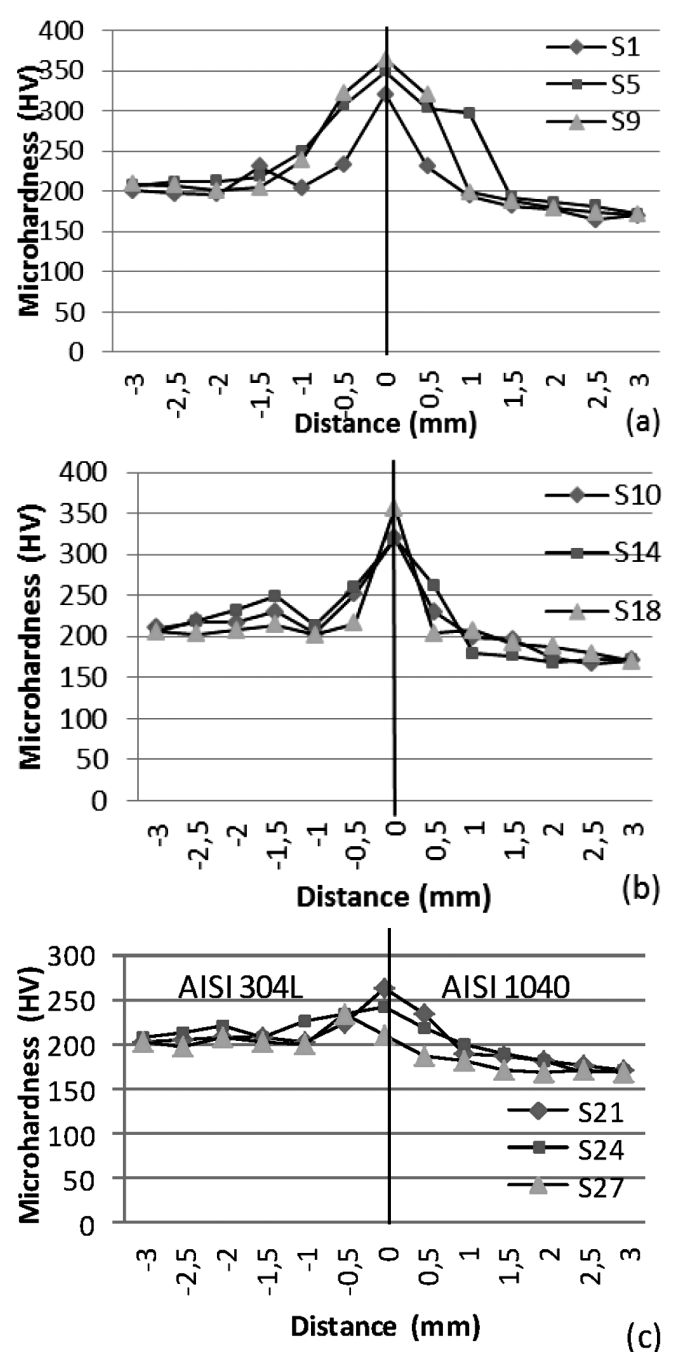

Figure 3: Typical microhardness distributions perpendicular to the interfaces of the joints: a) S1-S9, b) S10-S18 and c) S19-S27

Slika 3: Značilen potek trdote pravokotno na ravnino spoja vzorcev: a) S1-S9, b) S10-S18 in c) S19-S27 caused a grain refinement in the central region of the S13 weld adjacent to the FPDZ and DZ. It was observed that the rotational speed and frictional time affected the weld-region geometry and the width.

In $\mathrm{S} 27$, a high rotational speed caused a rapid heating to high temperatures at the interface. A greater volume of the viscous material was pushed out of the interface due to the increased axial shortening and temperature gradient. In addition, in the areas adjacent to the PDZs on three SEM images of the samples, overflows and slip bands due to the effect of the heat and the axial pressure are clearly seen. Away from the region of deformation the density of the slip bands decreased due to the axial pressure.

\subsection{Hardness-test results}

The hardness tests of the welded samples were carried out in the lines perpendicular to the weld interfaces of the friction-welded joints (Figure 3). Similar microhardness profiles were observed for all the welds. The microhardness values for the weld zones were much higher than those for the parent steels. The microhardness was the highest at the interface for all the joints, decreasing toward the main material. A partial presence of martensite was the reason for an increase in the hardness of the weld zone ${ }^{16}$ of the AISI 1040 steel, while a higher hardness of steel AISI 304L was due to the grain refinement. ${ }^{9,10,17}$ Among the joints, the highest hardness value was measured for sample $\mathrm{S} 1$, due to a low rotational speed and a higher frictional time causing a more severe plastic deformation.

The temperatures of the weld zones, during the friction welding, were measured with the IGA 15 PLUS infrared temperature-measurement device (Figure 4) and they were between $1025{ }^{\circ} \mathrm{C}$ and $1214{ }^{\circ} \mathrm{C}$. The temperature of a weld zone was directly affected and varied by the increasing frictional time. The increasing hardness of the interface of a friction-welded joint and the degree of deformation varied in dependence of the decreasing rotational speed. With a low rotational speed, the material of the interface was not sufficiently viscous. How-

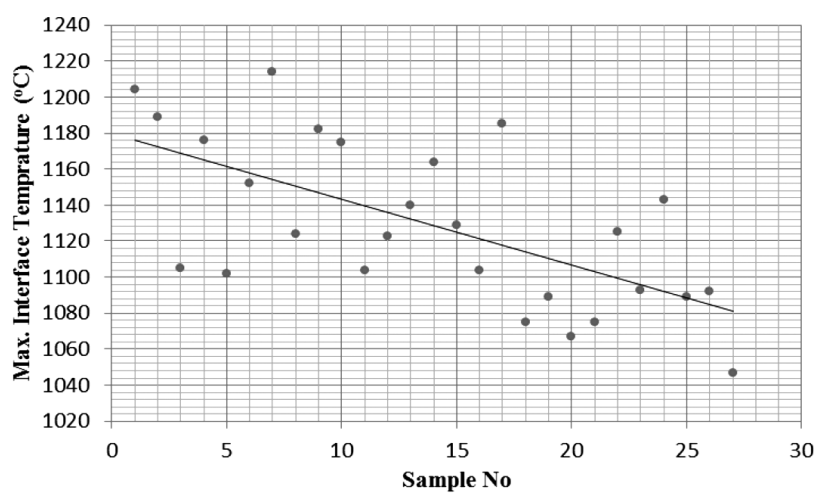

Figure 4: Temperatures of friction-welded joints Slika 4: Temperature pri tornem varjenju spojev 


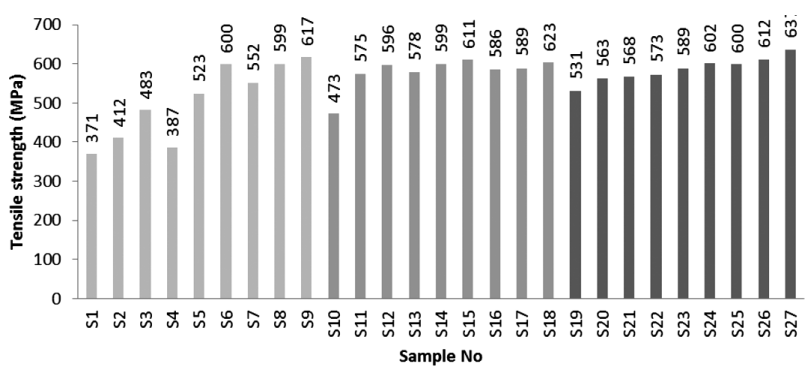

Figure 5: Tensile-test results for friction-welded joints of dissimilar materials

Slika 5: Rezultati nateznih preizkusov torno zvarjenih spojev različnih materialov

ever, looking at the hardness values for all the samples, the hardness values for the AISI 304L austenitic stainless steels were higher than for the AISI 1040 mediumcarbon steels due to the deformation hardening. The main reasons for this difference are the heat-transfer capacity and the yield strength of the stainless steels that are $60 \%$ higher than those of the medium-carbon steels. ${ }^{18,19}$ The lowest hardness and the lowest temperature were obtained for specimen S27, at the rotational speed of $1700 \mathrm{r} / \mathrm{min}$, frictional pressure of $50 \mathrm{MPa}$ and frictional time of $4 \mathrm{~s}$.

\subsection{Tensile-test results}

Figure 5 shows typical tensile strengths for the friction-welded joints consisting of dissimilar materials of AISI 304L and AISI 1040 tested at a strain rate of $1 \cdot 10^{-2} \mathrm{~s}^{-1}$. The tensile fracture surfaces of the frictionwelded joints are illustrated in Figure 6. All the samples failed in the area adjacent to the HAZ on the AISI 1040 side. The failure distance from the welding line increases depending on the higher rotational speed and frictional pressure (Table 4). The tensile strength of the welded joints depends markedly on the rotational speed and frictional time. The tensile-strength values for the FW joints were from $371 \mathrm{MPa}$ to $637 \mathrm{MPa}$, and the highest tensile strength was exhibited by $\mathrm{S} 27$ welded at the rate of $1700 \mathrm{r} / \mathrm{min}$ and frictional time of $4 \mathrm{~s}$. The increase in the tensile strength was due to the heat input and high plastic deformation that occurred at the interface of both

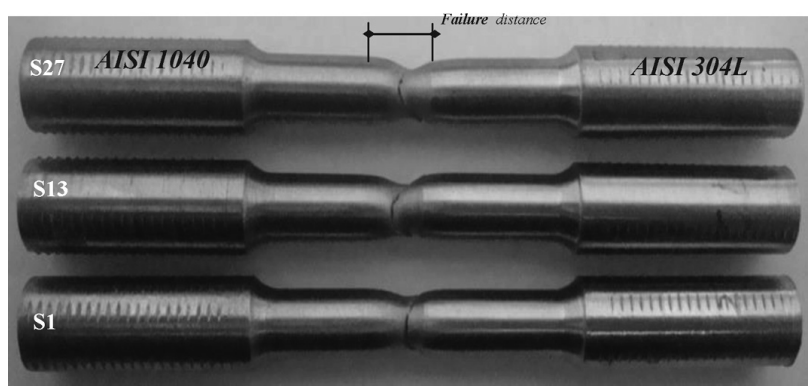

Figure 6: Typical failure locations on the tensile-test samples of friction-welded joints

Slika 6: Značilno področje porušitve pri nateznem preizkusu vzorcev s torno zvarjenim spojem steels as a result of the rotational speed and frictional pressure.

The lowest tensile-strength value was obtained for sample $\mathrm{S} 1$ at $1300 \mathrm{r} / \mathrm{min}$. This decrease in the tensile strength is associated with the width of the HAZ and the reactions in the AISI $1040 \mathrm{HAZ}^{17}$, causing a grain refinement of the microstructure, the $\sigma$-phase and the $\delta$-ferrite ${ }^{10,17,20}$ in the HAZ of AISI 304L. The occurrence of $\mathrm{Cr}_{23} \mathrm{C}_{6}, \mathrm{Cr}_{7} \mathrm{C}_{3}$ and $\mathrm{Fe}_{7} \mathrm{C}_{5}$ was confirmed with an X-ray analysis and an EDS analysis of the friction-welded joints and the occurrence of these phases in the HAZs has an important effect on the tensile strengths of the joints. Additionally, the formation of these phases could partly increase the hardness at the interface..$^{21}$ Due to a longer frictional time the volume of the viscous material

Table 4: Tensile results for AISI 304L/AISI 1040 friction welds Tabela 4: Rezultati nateznih preizkusov torno zvarjenih spojev AISI 304L/AISI 1040

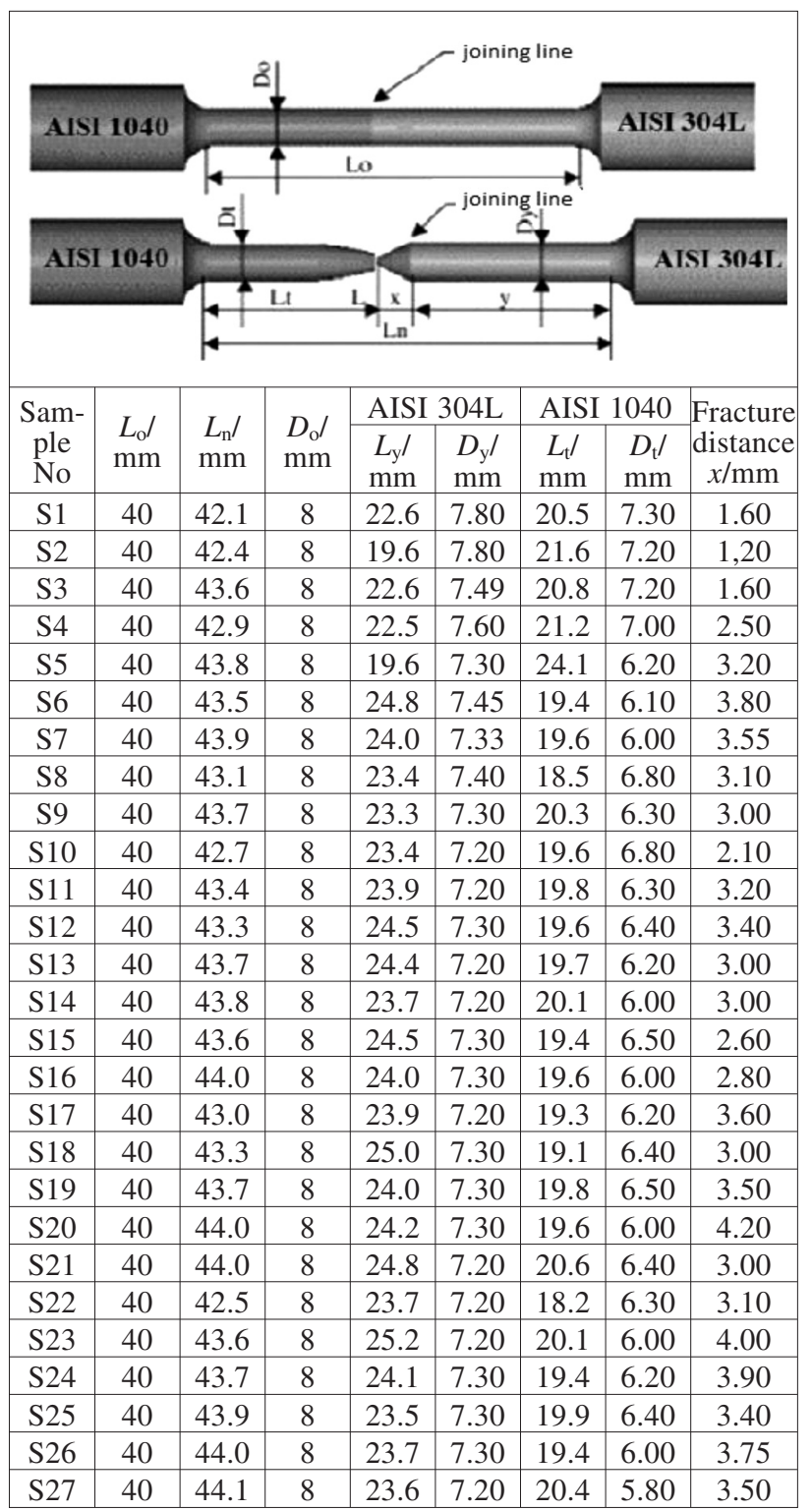




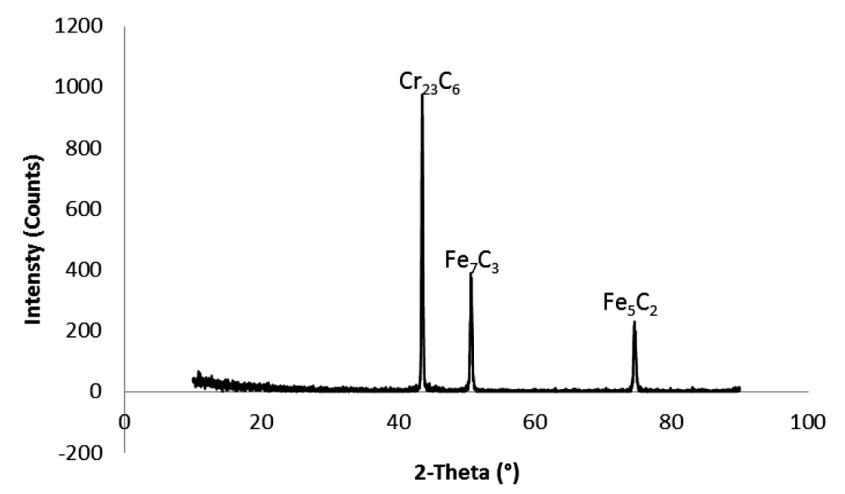

Figure 7: Result of XRD analysis for sample S13

Slika 7: Rentgenogram vzorca S13

Table 5: EDS analyses across the welding interfaces of frictionwelded samples S1, S13 and S27

Tabela 5: EDS-analiza preko ravnine spoja torno varjenih vzorcev S1, $\mathrm{S} 13$ in S27

\begin{tabular}{|c|c|c|c|c|c|c|c|}
\hline \multirow{2}{*}{$\begin{array}{c}\text { Sample } \\
\text { No }\end{array}$} & \multirow{2}{*}{$\begin{array}{c}\text { EDS } \\
\text { Points }\end{array}$} & \multicolumn{6}{|c|}{ Alloying elements $(w / \%)$} \\
\hline & & $\mathrm{C}$ & $\mathrm{Si}$ & $\mathrm{Cr}$ & $\mathrm{Mn}$ & $\mathrm{Fe}$ & $\mathrm{Ni}$ \\
\hline \multirow{5}{*}{ S1 } & point 1 & 0.62 & 0.22 & 0.54 & 2.54 & 92.7 & 0.68 \\
\hline & point 2 & 0.53 & 0.19 & 1.66 & 3.06 & 90 & 0.82 \\
\hline & point 3 & 0.55 & 0.33 & 10.06 & 3.64 & 79.4 & 4.89 \\
\hline & point 4 & 0.02 & 0.34 & 15.3 & 4.15 & 72.3 & 8.34 \\
\hline & point 5 & 0.37 & 0.49 & 16.45 & 3.74 & 65.43 & 8.03 \\
\hline \multirow{5}{*}{ S13 } & point 1 & 0.17 & 0.26 & 0.48 & 6.57 & 86.9 & 0.74 \\
\hline & point 2 & 0.59 & 0.31 & 6.07 & 6.86 & 81.17 & 2.98 \\
\hline & point 3 & 0.29 & 0.45 & 17.3 & 6.60 & 66.5 & 8.40 \\
\hline & point 4 & 0.24 & 0.50 & 17.46 & 6.58 & 62.38 & 9.61 \\
\hline & point 5 & 0.10 & 0.59 & 17.5 & 6.27 & 68.6 & 9.53 \\
\hline \multirow{5}{*}{ S27 } & point 1 & 0.04 & 0.21 & 0.53 & 6.38 & 88.3 & 0.69 \\
\hline & point 2 & 0.69 & 0.19 & 0.68 & 6.03 & 90.4 & 0.94 \\
\hline & point 3 & 0.03 & 0.45 & 10.7 & 6.21 & 74.3 & 4.23 \\
\hline & point 4 & 0.45 & 0.44 & 12.8 & 5.95 & 68.8 & 4.99 \\
\hline & point 5 & 0.39 & 0.44 & 18.1 & 6.90 & 62.3 & 8.72 \\
\hline
\end{tabular}

transferred at the weld interface decreased and the tensile strength was lowered (Figure 5). On the other hand, the tensile strength increased with a higher rotational speed and a lower frictional time. This shows that the formation and the width of the FPDZ, which is a result of the heat input and plastic deformation at the interface, have detrimental effects on the mechanical strength and,

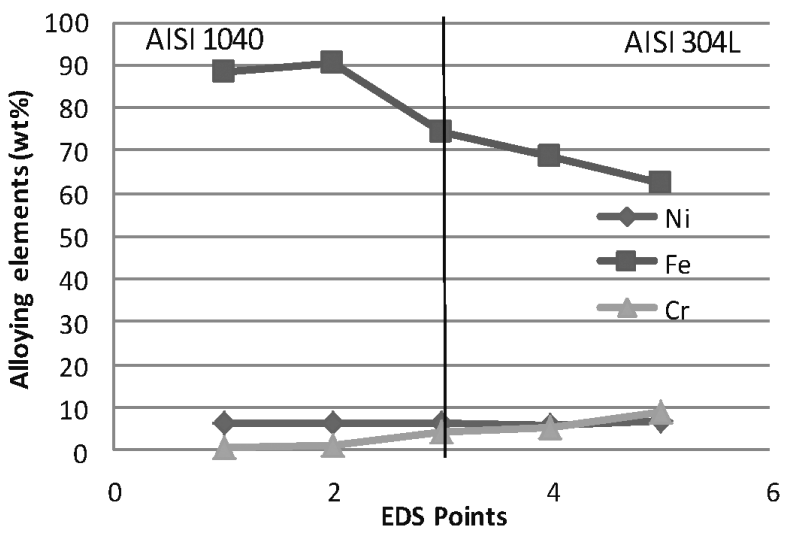

Figure 8: Concentration profiles of EDS analysis across the welding interface of friction-welded sample

Slika 8: Profil koncentracij pri EDS-analizi prereza stika pri torno zvarjenem vzorcu

consequently, on the process parameters of dissimilar friction-welded joints.

\subsection{X-ray and EDS analyses}

The results of the XRD analysis for friction-welded joint $\mathrm{S} 13$ are shown in Figure 7. The results confirm the presence of the $\mathrm{Cr}_{23} \mathrm{C}_{6}, \mathrm{Cr}_{7} \mathrm{C}_{3}$ and $\mathrm{Fe}_{5} \mathrm{C}_{2}$ compounds at the interface of the welded joints. SEM micrographs and EDS-analysis points of friction-welded joints S1, S13 and $\mathrm{S} 27$ are presented in Figure 2. In all the SEM images, the following EDS-analysis points are marked: point 1 (the AISI 1040 side), point 2 (the deformed zone), point 3 (the fully plasticized deformed zone), point 4 (the deformed zone of AISI 304L) and point 5 (on the AISI 304L side). The EDS-analysis results of samples of S1, S13 and S27 are also given in Table 5.

The results of the elemental analysis and microstructural examination in the interface regions of the friction-welded joints clearly demonstrated that different amounts of $\mathrm{C}, \mathrm{Fe}, \mathrm{Cr}, \mathrm{Si}, \mathrm{Ni}$ and $\mathrm{Mn}$ were obtained. Additionally, the EDS analysis of the interfaces of the friction-welded samples revealed that there was a transition of $\mathrm{Cr}$ and $\mathrm{Ni}$ from AISI 304L to AISI 1040. Furthermore, there was a Fe transition from AISI 1040 to
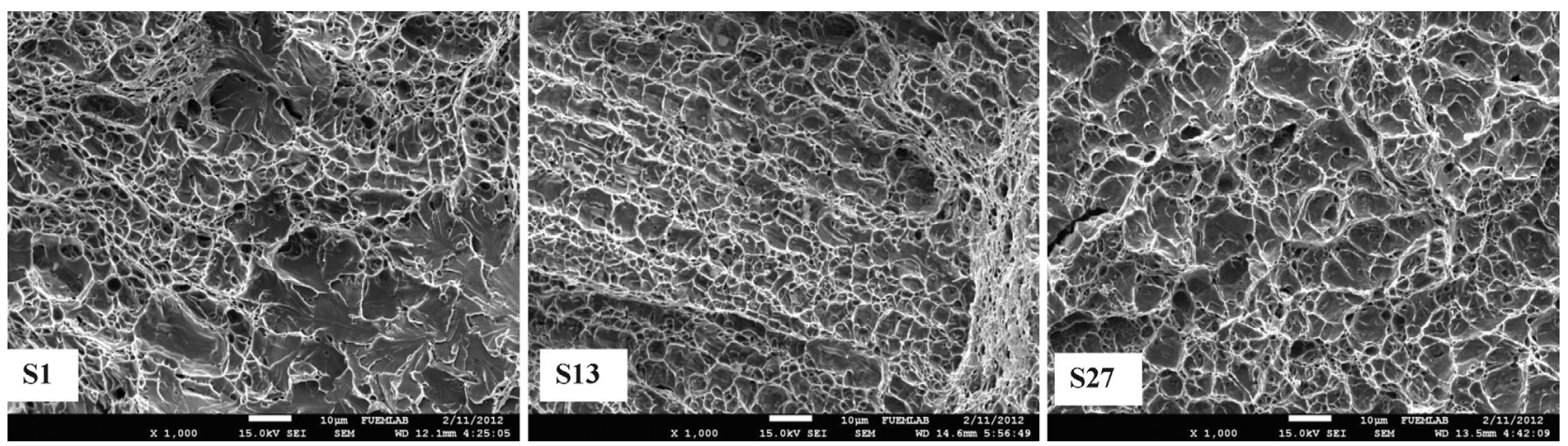

Figure 9: SEM micrographs of fracture surfaces after the tensile test of friction-welded samples S1, S13 and S27 Slika 9: SEM-posnetki provršine preloma po nateznem preizkusu torno zvarjenih vzorcev S1, S13 in S27 
the AISI 304L austenitic stainless steel, as seen in the concentration profiles of S13 in Figure 8.

\subsection{Fractography}

Figure 9 shows images of the fracture surfaces after the tensile test of friction-welded samples S1, S13 and S27. Examining the fracture-surface images, it was found that the fractures resulting from the tensile test mostly occurred on the AISI 1040 side, and especially ductile fractures in the form of quasi-cleavages were observed in the dimples. Moreover, all the samples showed a ductile fracture behavior; as seen on the SEM photographs of the fracture surfaces of the FW joints, these images resemble spider webs.

\section{CONCLUSIONS}

In this study, the following conclusions were made after a thorough investigation of the effects of the process parameters on the microstructure and mechanical properties of the friction-welded joints of the AISI 1040/AISI 304L steels:

1. The friction-welded AISI 1040 and AISI 304L steels were free of pores and cracks. A grain-size reduction occurred in the DZ of both materials. It was observed with SEM and EDS analyses that a transition of the materials occurred in the friction-weld zone.

2. Microstructural studies showed a presence of four different regions at the welding interface: a fully plasticized deformed zone, a partially deformed zone, a deformed zone and the base materials. The widths of the FPDZ and DZ of the joints were mainly affected by the frictional time and rotational speed. The use of a higher rotational speed and a lower frictional time increased the tensile strength of a friction-welded AISI 1040/AISI 304L steel couple. This shows that the formation of a FPDZ, which is a result of the heat input and plastic deformation at the interface, has a detrimental effect on the mechanical strength and, consequently, on the process parameters of dissimilar friction-welded joints, therefore, it needs to be controlled.

3. The highest tensile strength and a low microhardness were obtained very close to the AISI 1040 parent material of friction-welded sample S27 using a rotational speed of $1700 \mathrm{r} / \mathrm{min}$, a frictional pressure of $50 \mathrm{MPa}$ and a frictional time of $4 \mathrm{~s}$. Depending on the formation of the FPDZ and DZ, a decrease in the tensile strength was detected because of the grainrefined microstructure, $\sigma$-phase, $\delta$-ferrite and an increase in the frictional time.

\section{Acknowledgements}

The authors wish to thank the University of Firat Research Fund for the support of this work under the FUBAP-2054 project.

\section{REFERENCES}

${ }^{1}$ A. Aran, Stainless steel production standards and using, STY, Istanbul, Turkey, 2003

${ }^{2}$ ASM, Metals handbook, vol.8, 1973, 424

${ }^{3}$ R. J. Castro, J. J. De Cadenet, Welding metallurgy of stainless steel and heat- resisting steels, Cambridge University Press, Cambridge 1974

${ }^{4}$ J. J. Demo, Structure, Constitution, and General Characteristics of Wrought Ferritic Stainless Steels, ASTM, Philadelphia 1977, doi:10.1520/STP619-EB

${ }^{5}$ J. C. Lippold, D. J. Kotecki, Welding metallurgy and weldability of stainless steels, $1^{\text {st }}$ ed., Wiley-Interscience, 2005

${ }^{6}$ M. Erdoğan, Materials science and engineering materials 1, Ankara, Turkey, 2002, 326-331

${ }^{7}$ K. G. K. Murti, S. Sundaresan, Parameter optimization in friction welding dissimilar materials, Metal Construction, (1983), 331-335

${ }^{8}$ K. S. Mortensen, C. G. Jensen, L. C. Conrad, F. Losee, Mechanical properties and microstructures of intertia friction welded 416 stainless steel, Welding Journal, 80 (2001) 11, 268-273

${ }^{9}$ M. Sahin, H. E. Akata, An experimental study on friction welding of medium carbon and austenitic stainless steel components, Industrial Lubrication and Tribology, 56 (2004) 2, 122-129, doi:10.1108/ 00368790410524074

${ }^{10} \mathrm{~N}$. Özdemir, Investigation of the mechanical properties of frictionwelded joints between AISI 304L and AISI 4340 steel as a function rotational speed, Materials Letters, 59 (2005) 19-20, 2504-2509, doi:10.1016/j.matlet.2005.03.034

${ }^{11}$ V. V. Satyanarayana, G. Madhusudhan Reddy, T. Mohandas, Dissimilar metal friction welding of austenitic-ferritic stainless steels, Journal of Materials Processing Technology, 160 (2005) 2, 128-137, doi:10.1016/j.jmatprotec.2004.05.017

${ }^{12} \mathrm{~S}$. Celik, I. Ersozlu, Investigation of the mechanical properties and microstructure of friction welded joints between AISI 4140 and 1050 steels, Materials \& Design, 30 (2009) 4, 970-976, doi:10.1016/ j.matdes.2008.06.070

${ }^{13}$ I. Kirik, N. Özdemir, Weldability and joining characteristics of AISI 420/AISI 1020 steels using friction welding, International Journal of Materials Research, 104 (2013) 8, 769-775, doi:10.3139/146.110917

${ }^{14}$ P. Sathiya, S. Aravindan, A. Noorul Haq, K. Paneerselvam, Optimization of friction welding parameters using evolutionary computational techniques, Journal of Materials Processing Technology, 209 (2009) 5, 2576-2584, doi:10.1016/j.jmatprotec.2008.06.030

${ }^{15}$ İ. Kırık, N. Özdemir, F. Sarsilmaz, Microstructure and Mechanical Behaviour of Friction Welded AISI 2205/AISI 1040 Steel Joints, Materials Testing, 54 (2012) 10, 683-687, doi:10.3139/120.110379

${ }^{16} \mathrm{O}$. Torun, I. Celikyürek, B. Baksan, Friction welding of $\mathrm{Fe}-28 \mathrm{Al}$ alloy, Intermetallics, 19 (2011) 7, 1076-1079, doi:10.1016/j.intermet. 2011.02.009

${ }^{17}$ N. Özdemir, F. Sarsilmaz, A. Hasçalik, Effect of rotational speed on the interface properties of friction-welded AISI 304L to 4340 steel, Materials \& Design, 28 (2007) 1, 301-307, doi:10.1016/j.matdes. 2005.06.011

${ }^{18}$ C. R. G. Ellis, Friction Welding, Some Recent Applications of Friction Welding, Weld. and Metal Fab., (1977), 207-213

${ }^{19}$ H. Ates, M. Turker, A. Kurt, Effect of friction pressure on the properties of friction welded MA956 iron-based superalloy, Materials \& Design, 28 (2007) 3, 948-953, doi:10.1016/j.matdes.2005.09.015 


\section{İ. KIRIK, N. ÖZDEMIR: EFFECT OF PROCESS PARAMETERS ON THE MICROSTRUCTURE ...}

${ }^{20}$ F. D. Duffin, A. S. Bahrani, Frictional Behaviour of Mild Steel in Friction Welding, Wear, 26 (1973) 1, 53-74, doi:10.1016/0043-1648 (73)90150-6

${ }^{21}$ D. Ananthapadmanaban, V. Seshagiri Rao, N. Abraham, K. Prasad Rao, A study of mechanical properties of friction welded mild steel to stainless steel joints, Materials \& Design, 30 (2009) 7, 2642-2646, doi:10.1016/j.matdes.2008.10.030 